\title{
ANALISIS ENERGI DAN EKSERGI PADA SISTEM HTR-10 SIKLUS TURBIN UAP
}

\author{
Dedy Priambodo', Erlan Dewita ${ }^{1}$, Ign. Djoko Irianto ${ }^{2}$ \\ ${ }_{1}$ Pusat Kajian Sistem Energi Nuklir, Jl. Kuningan Barat, Mampang Prapatan, Jakarta 12710 \\ ${ }^{2}$ Pusat Teknologi dan Keselamatan Reaktor Nuklir, Puspiptek, Serpong, Tangerang Selatan \\ Email: dedypriambodo@gmail.com
}

\begin{tabular}{|c|c|c|}
\hline Diterima & Diterima dalam bentuk revisi & Disetujui \\
\hline 16 Maret 2015 & 07 Mei 2015 & 20 Mei 2015 \\
\hline
\end{tabular}

\begin{abstract}
ABSTRAK
ANALISIS ENERGI DAN EKSERGI PADA SISTEM HTGR SIKLUS TURBIN UAP. Reaktor tipe HTGR merupakan reaktor yang rencana akan dibangun sebagai Reaktor Daya Eksperimental (RDE) pertama di Indonesia. Reaktor HTGR merupakan reaktor dengan suhu pendingin keluar reaktor tinggi $\left(686^{\circ} \mathrm{C} \sim 950^{\circ} \mathrm{C}\right)$, efisiensi termal tinggi serta mempunyai sistem keselamatan pasif dan melekat. Untuk mengetahui ketepatan efisiensi suatu pembangkit dipandang tidak cukup jika hanya mengacu pada efisiensi energi saja seperti yang didasarkan pada Hukum I Termodinamika, namun perlu dikombinasikan dengan pendekatan eksergi yang berdasarkan Hukum II Termodinamika. Karena itu, tujuan studi adalah melakukan analisis energi dan eksergi pada sistem HTGR siklus turbin uap untuk mengetahui kerugian/ kehilangan panas yang terjadi dalam komponen sistem pembangkit, sehingga dapat diketahui potensipotensi kerugian dan dapat dilakukan perbaikan. Metode yang digunakan adalah perhitungan menggunakan program cycle tempo dengan input data dari reaktor HTR-10. Hasil studi analisis dan evaluasi terhadap ireversibilitas sistem reaktor HTGR menggunakan siklus turbin uap menunjukkan bahwa reaktor merupakan komponen yang paling tidak efisien, persentase ireversibilitas sebesar $61,8 \%$, diantara seluruh komponen yang ada dalam sistem. Hal ini disebabkan ireversibilitas yang terjadi dalam transfer energi hasil reaksi pembelahan ke pendingin helium. Pembangkit uap, turbin, kondensor, adalah komponen penyumbang kerugian terbesar berikutnya. Hasil studi juga menunjukkan bahwa efisiensi sistem HTGR siklus turbin uap mempunyai potensi besar untuk dilakukan perbaikan sehingga mampu memberikan efek yang signifikan terhadap perbaikan efisiensi sistem.
\end{abstract}

Kata kunci: energi, eksergi, HTGR, analisis, turbin uap

\begin{abstract}
ENERGY AND EXERGY ANALYSIS ON THE STEAM TURBINE CYCLE OF HTGR SYSTEM. HTGR type reactor is planned to be built reactors as the first Experimental Power Reactor (RDE) in Indonesia. HTGR tipe reactor is a reactor with a high reactor outlet temperature $\left(\sim 900^{\circ} \mathrm{C}\right)$, high thermal efficiency and also it have inherent and passive safety systems. To determine the accuracy of the efficiency of a power plant is not enough if it merely refers to the energy efficiency just as it is based on the first law of thermodynamics, but it needs to be combined with exergy approach that is based on the second law of thermodynamics. Therefore, the purpose of the study is to analyze the energy and exergy of HTGR-steam turbine cycle system to determine the loss / heat loss that occurs in the power system components, so it can be seen the potential loss and can be repaired. The methodology used is a calculation using the program cycle due to the data input of the HTR-10 reactor. The results of analysis and evaluation of the irreversibility of HTGR reactor system using a steam turbine cycle shows that the reactor is a component of the least efficient, $61.8 \%$ irreversibility, among all components in the system. This is due to the irreversibility of energy transfer that occurs in the cleavage reaction proceeds to the helium coolant. Steam generators, turbines, condensers, is a component of the next largest contributor kerugia. The study shows that the efficiency of the steam turbine cycle HTGR system has great potential to be improved so it can provide a significant effect on the improvement of the efficiency of the system.
\end{abstract}

Keywords: energy, exergy, HTGR, analysis, steam turbine 


\section{PENDAHULUAN}

Reaktor tipe HTGR merupakan reaktor yang rencana akan dibangun sebagai Reaktor Daya Eksperimental (RDE) pertama di Kawasan Puspiptek, Serpong. Reaktor HTGR merupakan reaktor dengan suhu pendingin keluar reaktor tinggi $\left(686^{\circ} \mathrm{C} \sim 900^{\circ} \mathrm{C}\right)^{[1]}$, efisiensi termal tinggi serta mempunyai sistem keselamatan pasif dan melekat. Reaktor dikarakterisasi dengan penggunaan grafit sebagai moderator dan reflektor, gas helium sebagai pendingin yang bersifat inert dan mempunyai fase tunggal, bahan bakar partikel berlapis dan teras berdensitas daya rendah. Penggunaan bahan teras yang bersifat tahan panas dikombinasi dengan pendingin helium menyebabkan suhu pendingin dapat mencapai $900^{\circ} \mathrm{C}$. Suhu pendingin keluar reaktor yang tinggi menyebabkan reaktor HTGR sangat potensial untuk tujuan kogenerasi, hal ini terkait kemampuan memasok panas proses industri dalam jangkauan yang lebih luas dibanding reaktor tipe lain, seperti tipe LWR.

Setiap jenis PLTN mempunyai efisiensi termal yang berbeda tergantung pada jenis reaktor dan siklus termodinamika yang digunakan. Reaktor jenis LWRs yang memanfaatkan siklus turbin uap (Siklus Rankine) mempunyai efisiensi dibawah 33\% sementara itu HTGR mempunyai range efisiensi berbeda sesuai dengan siklus termodinamika yang digunakan. Sistem HTGR Siklus Rankine mempunyai efisiensi berkisar 39\% untuk PLTN skala besar (PLTN Peach Bottom 1 dan Fort St. Vrain di Amerika serikat) dan 25\% untuk PLTN skala kecil (PLTN AVR Jerman dan HTR-10 Tiongkok). Efisisensi HTGR tertinggi jika dikopel dengan siklus turbin gas (Siklus Bryton) yaitu berkisar pada 44\% untuk sistem HTGR turbin gas indirect cycle dan $48 \%$ pada sistem HTGR turbin gas direct cycle ${ }^{[1]}$. Namun, besarnya efisiensi pembangkit dipandang masih belum menggambarkan efisiensi yang sebenarnya dimana efisiensi tersebut masih dapat ditingkatkan. Terdapat beberapa cara yang dapat dilakukan untuk meningkatkan efisiensi pembangkit. Pertama, dengan cara melakukan perbaikan terhadap kerugian atau kehilangan panas yang terjadi di dalam sistem panas pembangkit. Kedua, efisiensi pembangkit juga dapat tingkatkan melalui penerapan sistem kogenerasi dimana panas pembangkit digunakan selain untuk produksi listrik, juga dimanfaatkan untuk panas proses industri atau produksi lainnya. Pemanfaatan panas ini yang dapat meningkatkan efisiensi reaktor. Meningkatkan efisiensi pembangkit merupakan salah satu cara untuk meningkatkan keekonomian PLTN.

Saat ini, besarnya efisiensi pembangkiti ditentukan hanya mengacu pada efisiensi energi saja seperti yang didasarkan pada Hukum I Termodinamik dan metode tersebut dirasa kurang menggambarkan aspek-aspek penting dari pemanfaatan energi. Karena itu perlu dikombinasikan dengan pendekatan eksergi yang berdasarkan Hukum II Termodinamika untuk mengetahui ketepatan besarnya efisensi pemabangkit. Karena itu, perlu dilakukan perhitungan dan analisis untuk mengetahui ketepatan tingkat efisiensi suatu pembangkit yaitu dengan cara menganalisis eksergi yang juga dapat digunakan untuk mengidentifikasikan jenis, penyebab, dan lokasi terjadinya kerugian atau kehilangan panas pada sistem dan sub-sistem termal, sehingga perbaikan-perbaikan serta peningkatan kualitas dapat dilakukan ${ }^{[2]}$. Salah satu usaha untuk meningkatkan efisiensi panas dari pembangkit listrik dapat dilakukan dengan mengurangi ireversibilitas dari masing-masing komponen dalam pembangkit, sehingga analisis ireversibilitas komponen pembangkit perlu dilakukan. Beberapa studi terdahulu terkait analisis ireversibilitas telah dilakukan pada PLTN yang menggunakan reaktor tipe CANDU[3], BWR ${ }^{[4]}$, PWR $^{[5]}$ dan pada sistem superheater PLTN dengan pengaplikasian bahan bakar fosil[[]. Masing-masing tipe PLTN ini memiliki sistem yang berbeda, yang akan menghasilkan analisis dan hasil yang berbeda. Namun demikian, studi analisis irreversibilitas pada PLTN dengan reaktor tipe High Temperature Gas Cooled Reactor (HTGR) masih belum menjadi perhatian para peneliti.

Dalam rangka untuk mendukung program BATAN dalam membangun dan mengoperasikan Reaktor Daya Eksperimental (RDE) yang direncanakan bertipe HTGR dan daya 10 MWth, maka pada studi ini digunakan data dari reaktor HTR-10 milik Tiongkok 
yang dianggap mempunyai kesesuaian dengan tipe RDE yang akan dibangun. Studi tentang analisis energi dan eksergi ini dilakukan untuk mengevaluasi ireversibilitas pada sistem termal HTGR yang dikopel dengan sistem turbin uap (Siklus Rankine). Hasil analisis ini diharapkan dapat menjadi masukan untuk menentukan dimana potensi-potensi kerugian atau kehilangan panas dan perbaikan yang harus dilakukan terhadap efisiensi pembangkit HTR-siklus turbin uap.

\section{METODOLOGI}

\subsection{Teori}

\section{Sistem Reaktor HTR-10}

Sistem reaktor HTR-10 merupakan reaktor HTR yang menggunakan tipe bahan bakar bola (pebble) berdaya $10 \mathrm{MW}$ th. Diagram alir HTR-10 dengan pembangkit uap, sistem turbin uap, pompa air umpan, alat pemanas umpan dan pemanas untuk district heating ditunjukkan pada Gambar 1. Pada untai primer, helium masuk pada 3,04 $\mathrm{MPa} / 250^{\circ} \mathrm{C}$ dan keluar reaktor pada $3,0 \mathrm{MPa} / 700^{\circ} \mathrm{C}$ dengan laju alir $4,3 \mathrm{~kg} / \mathrm{s}$. Sementara itu pada untai sekunder, air umpan masuk pembangkit uap (Steam Generator-SG) pada temperatur $104^{\circ} \mathrm{C}$ dan keluar berupa uap lewat jenuh menuju turbin pada $435^{\circ} \mathrm{C} / 3,43 \mathrm{MPa}$. Laju alir air umpan maupun uap adalah 3,49 kg/s. Daya listrik yang dibangkitkan turbin-generator sebesar 2.5 $\mathrm{MWe}^{[8]}$.

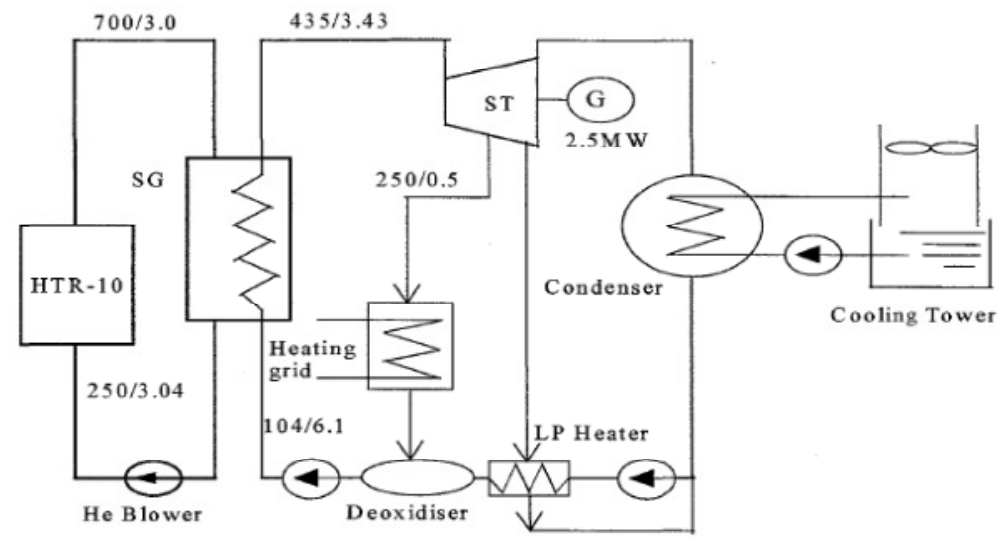

Gambar 1. Diagram Alir HTR-10 Siklus Turbin Uap ${ }^{[8]}$

\section{Konsep Eksergi}

Eksergi adalah jumlah maksimum kerja net yang diperoleh ketika aliran materi dibawa dari keadaan awal menuju keadaan mati (dead state) melalui proses yang melibatkan interaksi hanya dengan lingkungan ${ }^{[9]}$. Suatu sistem dikatakan berada dalam dead state ketika berada dalam kesetimbangan termal, mekanik dan kimia dengan lingkungan. Dalam analisis, penting untuk memahami perbedaan antara energi dan eksergi. Hal ini penting untuk mempertimbangkan kualitas dan kuantitas energi yang digunakan untuk mencapai tujuan tertentu dan kenyataannya akan dicapai penggunaan yang efisien dan efektif sumber daya energi. Salah satu kegunaan utama dari konsep eksergi adalah keseimbangan eksergi dalam analisis sistem termal. Keseimbangan eksergi (analisis eksergi) dapat dipandang sebagai pernyataan hukum energi degradasi. Analisis eksergi adalah alat untuk identifikasi jenis, lokasi dan besarnya kerugian termal. Identifikasi dan kualifikasi kerugian ini memungkinkan untuk evaluasi dan perbaikan desain sistem termal.

\section{Analisis Energi dan Eksergi}

Kesetimbangan Massa, energi dan Eksergi untuk setiap volume kontrol pada keadaan tunak dengan mengabaikan perubahan energi kinetik dan potensial dapat dinyatakan, masing-masing, dengan : 


$$
\begin{aligned}
& \sum_{i=1}^{n} m_{i}-\sum_{o=1}^{n} m_{o}=0 \\
& Q-W_{c v}=\sum_{o=1}^{n} m_{o} h_{o}-\sum_{i=1}^{n} m_{i} h_{i} \\
& W_{c v}=W_{u}=\sum_{i=1}^{n} m_{i}\left(h_{i}-T_{0} s_{i}\right)-\sum_{o=1}^{n} m_{o}\left(h_{o}-T_{0} s_{i}\right)-T_{0} S_{\text {gen }} \\
& \sum E x_{\text {heat }}-\sum E x_{\text {work }}+\sum E x_{i}-\sum E x_{o}=\sum E x_{\text {dest }} \\
& \sum E x_{\text {heat }}=\sum\left(1-\frac{T_{0}}{T}\right) Q \\
& \sum E x_{\text {work }}=W \\
& \sum E x_{i / o}=\sum m_{i / o} \cdot \varepsilon_{i / o}
\end{aligned}
$$

Persamaan (1) merupakan persamaan kekekalan massa, sedangkan persamaan (2a) dan (2b) adalah persamaan energi Hukum I Termodinamika dan persamaan kerja aktual (Hukum Ii Termodinamika). Dimana Q dan W merupakan net heat input dan work output, Wu adalah kerja aktual, $\mathrm{m}$ adalah laju alir massa dari fluida, $\mathrm{h}$ adalah entalpi, s adalah entropi, tanda i, o dan 0 merupakan relasi dari masukan, keluaran dan kondisi dead state, Sgen adalah laju produksi entropi dalam suatu proses sebagai akibat ireversibilitas, Exdest adalah eksergi yang hancur, Exheat adalah laju perpidahan eksergi netto dari panas pada temperatur T, dan T adalah temperatur dimana dimana perpindahan panas berlangsung. Sedangkan $\varepsilon_{\mathrm{i} / \mathrm{o}}$ adalah eksergi spesifik yang masuk dan keluar sistem. Dalam suatu sistem tunak, untuk mendapatkan kerja maksimum maka semua proses yang berlangsung dalam sistem harus reversible/ dapat balik sempurna, dan kondisi fluida yang keluar dari sistem harus dalam kesetimbangan termodinamika dengan lingkungan/dead state ${ }^{[9]}$. Untuk itu, guna mendapatkan kerja reversible atau kerja maksimum $\left(\mathrm{W}_{\mathrm{umax}}\right)$ maka $\mathrm{S}_{\mathrm{gen}}$ diset $=0$ sehingga persamaan (2b) menjadi:

$$
W_{c v}=W_{u}=\sum_{i=1}^{n} m_{i}\left(h_{i}-T_{0} s_{i}\right)-\sum_{o=1}^{n} m_{o}\left(h_{o}-T_{0} s_{i}\right)
$$

Jika ditinjau dari satu aliran masuk dan keluar pada suatu komponen maka kerja reversible dapat dirumuskan menjadi:

$$
W_{u}=m\left[\left(h_{i}-h_{o}\right)-T_{0}\left(s_{i}-s_{o}\right)\right]
$$

Laju ireversibilitas (kerja yang hilang) I pada proses aliran tunak dalam kontrol volume merupakan selisih dari kerja maksimum/reversible dengan kerja aktual, yang sebanding dengan eksergi yang hancur dalam proses aktual.

$$
I=E x_{\text {dest }}=W_{u \max }-W_{u}=T_{0} S_{\text {gen }}
$$

Sedangkan efisiensi energi $\left(\eta_{\mathrm{I}}\right)$ dan efisiensi eksergi $\left(\eta_{\mathrm{II}}\right)$ HTR-10 MW $\mathrm{W}_{\text {th }}$ siklus turbin uap dapat ditulis sebagai berikut:

$$
\begin{aligned}
& \eta_{I}=\frac{\text { Energi_keluar }}{\text { Energi_masuk }} \cdot 100 \%=\frac{W_{\text {turbin }}}{Q_{\text {reaktor }}} \cdot 100 \% \\
& \eta_{I}=\frac{\text { Eksergi_keluar }}{E \text { Esergi_masuk }} \cdot 100 \%=\frac{E x_{\text {work }}}{E x_{\text {reaktor }}} \cdot 100 \%=\frac{W_{\text {turbin }}}{Q_{\text {reaktor }}} \cdot 100 \%
\end{aligned}
$$

Pada studi ini, kondisi operasi pembangkit diambil sesuai dengan kondisi siklus turbin uap HTR-10, namun dilakukan penyesuaian dengan menghilangkan penukar panas district heating dan menggantinya dengan dearator (pemanas air umpan sistem terbuka).

\section{Ireversibilitas Reaktor}

Untuk mendapatkan ireversibilitas reaktor, pertama yang harus dilakukan adalah menghitung kerja maksimum yang dapat dilakukan oleh pembelahan bahan fisil dalam bakar nuklir ${ }^{[10]}$. Dalam proses pembelahan, terutama pada produk hasil belah, masingmasing berada dalam keadaan steady state dan mempunyai energi kinetik sebesar 100 
MeV[10]. Jika fragmen hasil belah dianggap sebagai gas ideal dalam keadaan setimbang secara termodinamika, fragmen tersebut akan mempunyai temperatur belah T Tisi sehingga dengan persamaan kinetik gas ideal didapatkan $\frac{3}{2} k T_{f i s} \cong 100 \mathrm{MeV}$. Fragmen hasil belah dalam asumsi proses reversible dapat melakukan kerja maksimum, jika proses ini membawa fragmen belah pada keadaan setimbang dengan lingkungan pada temperatur $\mathrm{T}_{0}$, pada keadaan ini energi fragmen adalah $\mathrm{u}_{0}=\frac{3}{2} \mathrm{kT}_{0} \cong 0.0375 \mathrm{eV}$. Dengan demikian eksergi spesifik untuk fragmen belah ( $\left.\varepsilon_{\text {fisi }}\right)$, dapat dituliskan sebagai berikut:

$$
\varepsilon_{\text {fisi }}=\mathrm{w}_{\max }=\left(\mathrm{h}_{\text {fisi }}-\mathrm{h}_{0}\right) \mathrm{T}_{0}\left(\mathrm{~s}_{\text {fisi }}-\mathrm{s}_{0}\right)
$$

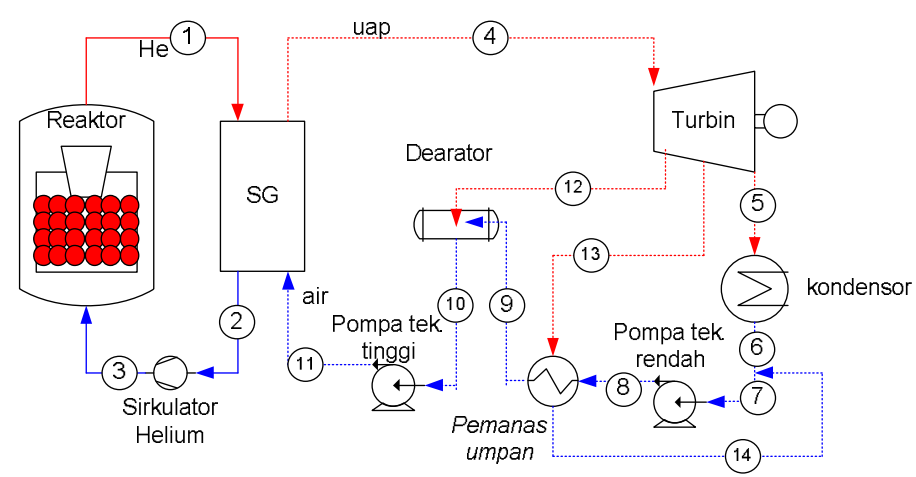

\section{Gambar 2. Diagram Alir HTR-10 Siklus Turbin Uap yang Digunakan pada Studi ini}

Atau dapat ditulis ulang menjadi

$$
\begin{aligned}
& \varepsilon_{\text {fisi }}=\mathrm{w}_{\text {max }}=\left(\mathrm{u}_{\text {fisi }}+P_{f i s i} \cdot \mathrm{v}_{\text {fisi }}\right)-\left(\mathrm{u}_{0}+P_{0} \cdot \mathrm{v}_{0}\right)+\mathrm{T}_{0}\left(\mathrm{~s}_{\text {fisi }}-\mathrm{s}_{0}\right) \\
& \varepsilon_{\text {fisi }}=\mathrm{w}_{\max }=\left(\mathrm{c}_{\mathrm{v}} T_{\text {fisi }}+P_{f i s i} \cdot \mathrm{v}_{\text {fisi }}\right)-\left(\mathrm{c}_{\mathrm{v}} \mathrm{T}_{0}+P_{0} \cdot \mathrm{v}_{0}\right)+\mathrm{T}_{0}\left(\mathrm{~s}_{\text {fisi }}-\mathrm{s}_{0}\right)
\end{aligned}
$$

Dimana $T_{\text {fisi }}$ sangat jauh lebih tinggi dari $\mathrm{T}_{0}$ sehingga persamaan di atas dapat di sederhanakan menjadi:

$$
\varepsilon_{\text {fisi }}=\mathrm{w}_{\max }=\mathrm{c}_{\mathrm{v}} T_{\text {fisi }} \cong u_{\text {fisi }}
$$

Dengan demikian eksergi dapat disamakan dengan energi pembelahan (ufisi), dengan kata lain seluruh energi pembelahan dapat dijadikan kerja. Eksergi dari reaksi pembelahan (Exfisi) sama dengan daya fisi ( $\left.Q_{\text {fisi }}\right)$ dan dihantarkan ke bola bahan bakar pada temperatur tetap $\left(\mathrm{T}_{\mathrm{BBN}, \mathrm{o}}\right)$. Karena temperatur bola bahan bakar jauh dibawah temperatur fragmen hasil belah, $T_{\text {fisi, }}$ bahan bakar dan permukaan lapisan Triso dianggap sama dalam perhitungan ini. Transfer daya dari fragmen belah ke bola bahan bakar sangat ireversible selama temperatur fisi ( $\left.T_{\text {fisi }}\right)$ jauh lebih tinggi dari temperatur tetap bahan bakar $\left(\mathrm{T}_{\text {ввN,o). }}\right.$. Sehingga eksergi dari bola bahan bakar pada temperatur tetap $\mathrm{T}_{\text {ввN,o adalah }}$

$$
(E x)_{B B N}=(E x)_{f i s i} \cdot\left(1-\frac{T_{0}}{T_{B B N, o}}\right)
$$

Sehingga ireversibilitas BBN dapat dituliskan menjadi

$$
I=(E x)_{f i s i}-(E x)_{B B N}=(E x)_{f i s i}\left(\frac{T_{0}}{T_{B B N, o}}\right)
$$

Dari BBN, seluruh daya akan dipindahkan ke pendingin helium. Sehingga eksergi helium adalah

$$
(E x)_{\text {helium }}=m_{\text {helium }}\left[\left(h_{o}-h_{i}\right)_{\text {reaktor }}-T_{0}\left(s_{o}-s_{i}\right)_{\text {reaktor }}\right]
$$

Sehingga ireversibilitas helium dapat dituliskan menjadi:

$$
\mathrm{I}_{\text {helium }}=(\mathrm{Ex})_{\mathrm{BBN}}-(\mathrm{Ex})_{\text {helium }}=(E x)_{\text {fisi }}\left(\frac{T_{o}\left(s_{\text {out }}-s_{\text {in }}\right)_{\text {reaktor }}}{\left(h_{\text {out }}-h_{\text {in }}\right)_{\text {reaktor }}}-\frac{T_{0}}{T_{B B N, 0}}\right)
$$


Karena Exfisi sebanding dengan $\mathrm{Q}_{\text {fisi }}=\mathrm{Q}_{\mathrm{R}}=\mathrm{m}_{\text {helium}}\left(\mathrm{h}_{\text {out }} \text {-hin) }\right)_{\text {reaktor }}$ sehingga dengan menggunakan volume kontrol hukum I termodinamika, serta tidak adanya kerja shaft, dan mengabaikan energi kinetik dan potensial, maka ireversibilitas reaktor dapat disusun menjadi:

$$
\begin{aligned}
& I_{\text {reaktor }}=I_{\text {fisi }}+I_{B B N}+I_{\text {Helium }} \\
& I_{\text {reaktor }}=0+(E x)_{\text {fisi }} \cdot\left(\frac{T_{0}}{T_{B B N, o}}\right)+(E x)_{\text {fisi }}\left(\frac{T_{o}\left(s_{\text {out }}-s_{\text {in }}\right)_{\text {reaktor }}}{\left(h_{\text {out }}-h_{\text {in }}\right)_{\text {reaktor }}}-\frac{T_{0}}{T_{B B N, 0}}\right) \\
& I_{\text {reaktor }}=0+(E x)_{\text {fisi }} \cdot\left(\frac{T_{0}}{T_{B B N, o}}\right)+(E x)_{\text {fisi }} \frac{T_{o}\left(s_{\text {out }}-s_{\text {in }}\right)_{\text {reaktor }}}{\left(h_{\text {out }}-h_{\text {in }}\right)_{\text {reaktor }}}-(E x)_{\text {fisi }} \frac{T_{0}}{T_{B B N, 0}} \\
& I_{\text {reaktor }}=(E x)_{\text {fisi }} \frac{T_{o}\left(s_{\text {out }}-s_{\text {in }}\right)_{\text {reaktor }}}{\left(h_{\text {out }}-h_{\text {in }}\right)_{\text {reaktor }}}=m_{\text {helium }}\left(h_{\text {out }}-h_{\text {in }}\right)_{\text {reaktor }} \cdot \frac{T_{o}\left(s_{\text {out }}-s_{\text {in }}\right)_{\text {reaktor }}}{\left(h_{\text {out }}-h_{\text {in }}\right)_{\text {reaktor }}} \\
& I_{\text {reaktor }}=m_{\text {helium }} T_{0}\left(s_{\text {out }}-s_{\text {in }}\right)_{\text {reaktor }}
\end{aligned}
$$

\section{Ireversibilitas Pembangkit Uap}

Neraca massa $\mathrm{m}_{2}=\mathrm{m}_{1}$

Neraca energi $\mathrm{Q}_{\mathrm{sG}}=\mathrm{m}_{1} .\left(\mathrm{h}_{2}-\mathrm{h}_{1}\right)$

Ireversibilitas IsG $=$ mhelium.To. $\left(\mathrm{S}_{2}-\mathrm{S} 1\right)+\mathrm{m}_{\text {steam. }} \cdot \mathrm{T}_{0} \cdot(\mathrm{s} 4-\mathrm{S} 11)$

\section{Ireversibilitas Sirkulator Helium}

Neraca massa $m_{2}=m_{3}$

Neraca energi $W_{s h}=m_{2} .\left(h_{3}-h_{2}\right)$

Ireversibilitas IsH $=$ mhelium. $\mathrm{T}_{0} .\left(\mathrm{s}_{3}-\mathrm{S}_{2}\right)$

\section{Ireversibilitas Turbin Uap}

Neraca massa $m_{4}=m_{12}+m_{13}+m_{5}$

Neraca Energi $\mathrm{W}_{\text {turbin }}=\mathrm{m}_{4} .\left(\mathrm{h}_{12}-\mathrm{h}_{4}\right)+\left(\mathrm{m}_{4}-\mathrm{m}_{12}\right) .\left(\mathrm{h}_{13}-\mathrm{h}_{12}\right)+\mathrm{m}_{5} .\left(\mathrm{h}_{5}-\mathrm{h}_{13}\right)$

Ireversibilitas $I_{\text {turbin }}=m_{4} T_{0}\left[\left(s_{12}-s_{4}\right)+\left(m_{4}-m_{12}\right)\left(s_{13}-s_{12}\right)+\left(m_{5}\right)\left(s_{5}-s_{12}\right]\right.$

\section{Ireversibilitas Kondensor}

Neraca massa $\mathrm{m}_{5}=\mathrm{m}_{6} ; \mathrm{m}_{23}=\mathrm{m}_{22}$

Neraca Energi $Q_{\text {kondensor }}=$ m5. $\left(\mathrm{h}_{6}-\mathrm{h}_{5}\right)$

Ireversibilitas kondensor, $I_{\text {kondensor }}=m_{\text {steam }} T_{0}\left[-\left(\frac{h_{6}-h_{5}}{T_{0}}\right)+\left(s_{6}-s_{5}\right)\right]$

\section{Ireversibilitas mixer}

Neraca massa $\mathrm{m}_{7}=\mathrm{m}_{6}+\mathrm{m}_{14}$

Ireversibilitas $\mathrm{I}_{\mathrm{mixer}}=\mathrm{m}_{7} . \mathrm{T}_{0 . \mathrm{S} 7}-\mathrm{m}_{6} . \mathrm{T}_{0 . \mathrm{S} 6}-\mathrm{m}_{14} . \mathrm{T}_{0} . \mathrm{S}_{14}$

\section{Ireversibilitas Pompa tekanan rendah}

Neraca massa $m_{7}=m_{8}$

Neraca Energi $W_{\mathrm{p} 1}=\mathrm{m}_{7} .\left(\mathrm{h} 8-\mathrm{h}_{7}\right)$

Ireversibilitas $\mathrm{I}_{\mathrm{p} 1}=\mathrm{m} 7 . \mathrm{T}_{0}$. $(\mathrm{s} 8-\mathrm{S} 7)$

\section{Ireversibilitas Pemanas Air umpan tertutup}

Neraca massa $\mathrm{m}_{8}=\mathrm{m}_{9} ; \mathrm{m}_{13}=\mathrm{m}_{14}$

Ireversibilitas IFwH $=\mathrm{m} 8 . \mathrm{T}_{0} .(\mathrm{s} 9-\mathrm{S} 8)-\mathrm{m}_{13} \cdot \mathrm{T}_{0} .(\mathrm{S} 14-\mathrm{S} 13)$

\section{Ireversibilitas Dearator}

Neraca massa $\mathrm{m}_{10}=\mathrm{m}_{9}+\mathrm{m}_{12}$

Ireversibilitas $\mathrm{I}_{\text {dearator }}=\mathrm{T}_{0} .\left(\mathrm{m}_{10 . \mathrm{S} 10}-\mathrm{m} 9 . \mathrm{S} 9-\mathrm{m}_{12 . \mathrm{S} 12}\right)$

\section{Ireversibilitas Pompa tekanan tinggi}

Neraca massa $m_{10}=m_{11}$

Neraca Energi $W_{\mathrm{p} 2}=\mathrm{m}_{10} .\left(\mathrm{h}_{11}-\mathrm{h}_{10}\right)$ 
Ireversibilitas $\mathrm{I}_{\mathrm{p} 2}=\mathrm{m}_{10} . \mathrm{T}_{0} .(\mathrm{S} 11-\mathrm{S} 10)$

\subsection{Metode Penelitian}

Pada studi ini, kondisi operasi pembangkit diambil sesuai dengan kondisi siklus turbin uap HTR-10, namun dilakukan penyesuaian dengan menghilangkan penukar panas district heating[8]. Kemudian siklus ini disimulasikan dengan menggunakan perangkat lunak komputer CycleTempo 5.0 untuk mendapatkan sifat termodinamika setiap alirannya, seperti Gambar 3. Sifat termodinamika tersebut kemudian dihitung energi dan eksergi setiap aliran dengan menggunakan persamaan pada subbab teori. Selanjutnya dilakukan perhitungan energi dan ireversibilitas pada setiap komponen dalam pembangkit. Dari perhitungan energi dan ireversibilitas kemudian dapat dihitung efisiensi pembangkit, distribusi eksergi dan persentase ireversibilitas komponen terhadap ireversibilitas total.

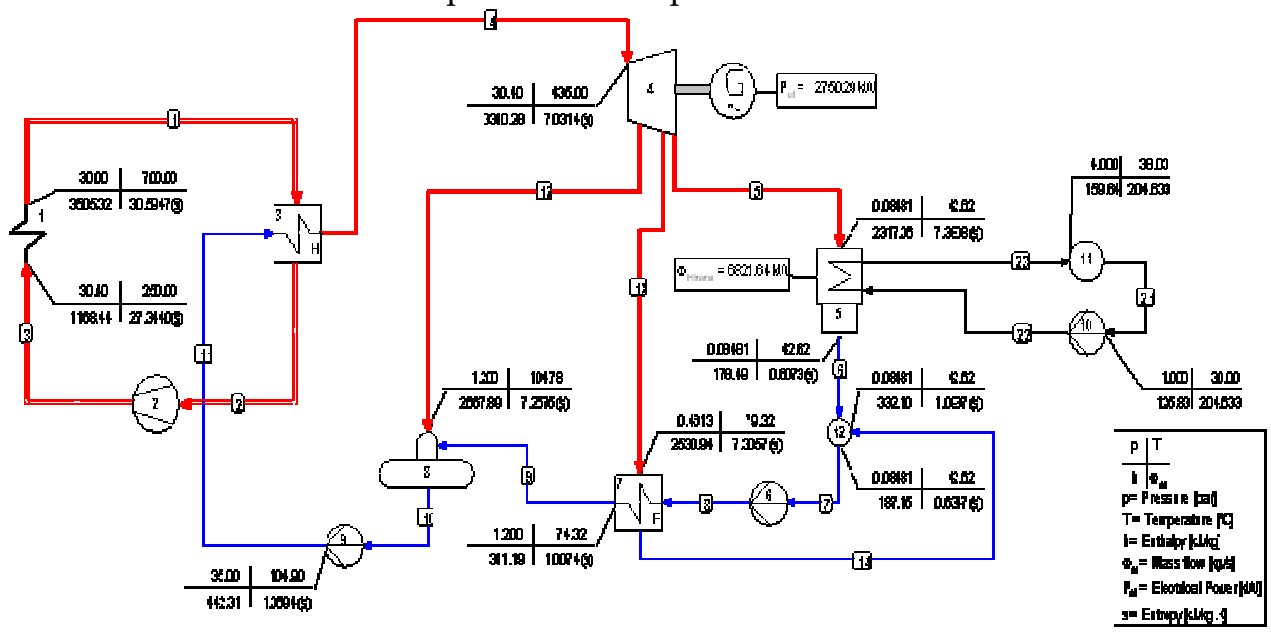

Gambar 3. Hasil Simulasi Siklus Turbin Uap HTR-10

Keterangan Gambar 3.

1. Reaktor pebble bed, 2. sirkulator helium, 3. pembangkit uap, 4. turbin uap, 5. kondensor, 6 dan 9 masing-masing adalah pompa air umpan tekanan rendah dan tekanan tinggi, serta 7 dan 8 adalah pemanas air umpan sistem tertutup dan terbuka (deaerator).

\section{HASIL DAN PEMBAHASAN}

Neraca energi dan eksergi dari HTR-10 siklus turbin uap dapat dilihat pada Tabel 1. Poin 1-3 yang merupakan untai utama pada sistem yang menggunakan fluida kerja helium. Sementara poin 4-14 adalah untai sekunder dengan fluida kerja air-uap. Dari perhitungan menggunakan persamaan (10) dan (11) dengan menggunakan data Tabel 2 didapatkan bahwa efisiensi baik energi maupun eksergi sistem HTR-10 suklis turbin uap hanya sebesar $25 \%$ atau jika dilihat dari Hukum I Termodinamika maka artinya sebesar 75\% energi panas yang dimasukkan kedalam sistem (panas reaktor) terbuang ke lingkungan melalui kondensor.

Kemudian jika kita melihat distribusi eksergi dari untai utama, seperti terlihat pada Gambar $4 a$, terlihat bahwa 61,7\% eksergi untai berasal dari reaktor, namun hanya 35,7\% yang bisa digunakan karena 19,23\% eksergi hancur didalam reaktor disebabkan ketidakefisienan transfer energi dari reaksi pembelahan ke pendingin helium. Kemudian terjadi pula ketidakefisienan dalam pendingin helium sebesar 6,81\% eksergi hancur. Dari maksimum energi yang terdapat dalam untai utama hanya sebesar 25,31 \% yang bisa ditransfer ke untai sekunder. 
Tabel 1. Neraca Energi dan Eksergi dari Simulasi

\begin{tabular}{|c|c|c|c|c|c|c|c|}
\hline Arus & $\begin{array}{c}\mathrm{m} \\
\mathrm{kg} / \mathrm{s}\end{array}$ & $\begin{array}{c}\mathrm{h} \\
\mathrm{kJ} / \mathrm{kg}\end{array}$ & $\begin{array}{c}\mathrm{s} \\
\mathrm{kJ} / \mathrm{kg} \cdot \mathrm{K}\end{array}$ & $\begin{array}{l}\mathrm{m} . \mathrm{h} \\
\mathrm{kJ} / \mathrm{s}\end{array}$ & $\%$ Energi & $\begin{array}{c}\text { Eksergi } \\
\mathrm{kJ} / \mathrm{s}\end{array}$ & \% Eksergi \\
\hline 1 & 4,279 & 3.505 .32 & 30,5947 & $14.998,91$ & $100,0 \%$ & $16,195.84$ & $100,0 \%$ \\
\hline 2 & 4,279 & $1,112.16$ & 27,3333 & 4.758 .82 & $31,7 \%$ & $10.186,26$ & $62,9 \%$ \\
\hline \multirow[t]{2}{*}{3} & 4,279 & $1.168,44$ & 27,3440 & $4.999,64$ & $33,3 \%$ & $10.413,20$ & $64,3 \%$ \\
\hline & & $\mathrm{BBN}$ & & $10.000,00$ & $66,7 \%$ & $10.000,00$ & $61,7 \%$ \\
\hline 4 & 3,571 & $3.310,28$ & 7,0314 & $11.821,01$ & $100,0 \%$ & $4.323,66$ & $100,0 \%$ \\
\hline 5 & 3,189 & $2.317,36$ & 7,3808 & $7.390,06$ & $62,5 \%$ & 275,67 & $6,51 \%$ \\
\hline 6 & 3,189 & 178,49 & 0,6073 & 569,20 & $4,8 \%$ & 3,07 & $0,07 \%$ \\
\hline 7 & 3,380 & 187,15 & 0,6347 & 632,57 & $5,35 \%$ & 4,45 & $0,11 \%$ \\
\hline 8 & 3,380 & 187,35 & 0,6348 & 633,24 & $5,36 \%$ & 5,02 & $0,12 \%$ \\
\hline 9 & 3,380 & 311,19 & 1,0074 & $1.051,82$ & $8,9 \%$ & 41,82 & $0,99 \%$ \\
\hline 10 & 3,571 & 437,25 & 1,3553 & $1.561,42$ & $13,2 \%$ & 117,72 & $2,78 \%$ \\
\hline 11 & 3,571 & 442,31 & 1,3594 & $1.579,49$ & $13,4 \%$ & 131,35 & $3,10 \%$ \\
\hline 12 & 0,191 & $2.667,89$ & 7,2575 & 509,57 & $4,3 \%$ & 90,60 & $2,14 \%$ \\
\hline 13 & 0,190 & $2.530,94$ & 7,3057 & 480,88 & $4,1 \%$ & 61,33 & $1,45 \%$ \\
\hline 14 & 0,190 & 332,10 & 1,0937 & 63,10 & $0,5 \%$ & 1,35 & $0,03 \%$ \\
\hline
\end{tabular}

Selain itu dari simulasi dengan menggunakan CycleTempo 5.0 didapat kondisi operasi sebagai berikut:

Tabel 2. Kondisi Operasi dan Kerja/Beban Panas dari Simulasi

\begin{tabular}{lll}
\hline Komponen & $\begin{array}{l}\text { Kondisi operasi } \\
\left({ }^{\circ} \mathbf{C} / \mathbf{b a r}\right)\end{array}$ & Kerja/beban panas $(\mathbf{k W})$ \\
\hline Reaktor & $700 / 30$ & $\pm 10.000(\mathrm{kWth})$ \\
Pembangkit uap & $239,16 / 29$ & $10.240(\mathrm{kWth})$ \\
Sirkulator helium & $250 / 30,4$ & $258,08(\mathrm{kWe})$ \\
Turbin & $435 / 30,4$ & $2.750,29(\mathrm{kWe})$ \\
Kondensor & $0,0842(\mathrm{jenuh})$ & $6.821,2(\mathrm{kWth})$ \\
Pompa Tekanan Rendah PTR & $44,72 / 1,2$ & $1,14(\mathrm{kWe})$ \\
Pemanas air umpan tertutup & $74,32 / 1,2$ & \\
Deaerator & $104,3 / 1,18$ & \\
Pompa Tekanan Tingg (PTT) & $104,9 / 35$ & $21,28(\mathrm{kWe})$ \\
Daya keluar netto (Daya turbin-daya pompa) & $2.469,86(\mathrm{kWe})$ \\
\hline
\end{tabular}

Analisis distribusi eksergi untai sekunder dapat dilihat pada gambar 4b. dimana 100\% eksergi maksimum yang keluar dari pembangkit uap 96,9\% berasal dari untai utama. Sementara itu 81,22\% eksergi diubah menjadi kerja di dalam turbin uap, dan sekitar 6,14\% eksergi hilang di kondensor dan 0,3\% eksergi hancur karena pencampuran fluida di dalamnya. Meskipun dalam kondensor terjadi kehilangan maupun kehancuran eksergi namun ini nampak lebih kecil dibanding dengan kerja yang dilakukan oleh turbin uap. Dari sini terlihat perbedaan antara Hukum I dan Hukum II Termodinamik. Dari pernyataan pada paragraf sebelumnya (menurut Hukum I Termodinamika) bahwa kondensor adalah satusatunya penyebab rendahnya efisiensi dari sistem (75\% energi terbuang di kondensor), sementara itu berdasar Hukum II Termodinamika terlihat bahwa kondensor hanya menyumbang kehilangan dan kehancuran eksergi yang rendah. Dari analisis eksergi ini dapat disimpulkan bahwa ada komponen-komponen lain yang berpengaruh (besar maupun kecil) terhadap efisiensi sistem, seperti turbin, pemanas air umpan dan pompa.

Dari Tabel 3. terlihat kehancuran eksergi pada tiap komponen dalam sistem. Eksergi yang hancur atau disebut ireversibilitas adalah parameter penting yang digunakan dalam analisis Hukum II Termodinamika, karena parameter ini memperlihatkan dengan jelas ketidakefisiensian dari komponen yang ada, Gambar 5 memperlihatkan ireversibilitas 
komponen, yang telah diurutkan dari yang terbesar hingga yang terkecil. Nampak bahwa ireversibilitas reaktor adalah yang terbesar kemudian diikuti pembangkit uap, turbin, kondensor, sistem pemanas air umpan, sirkulator helium, pompa tekanan tinggi, mixer dan pompa tekanan rendah.

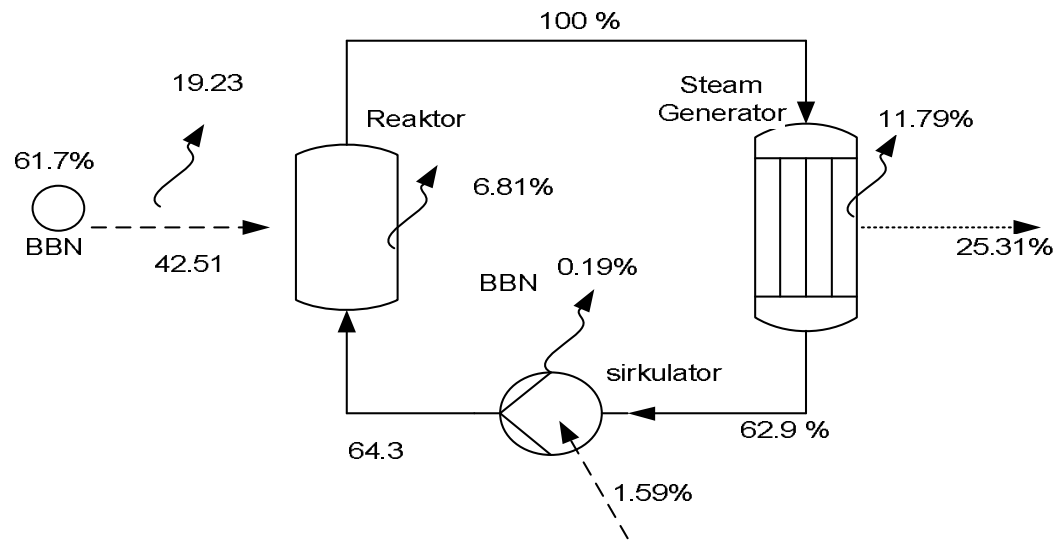

Gambar 4a. Distribusi Eksergi (\%) pada Untai Utama

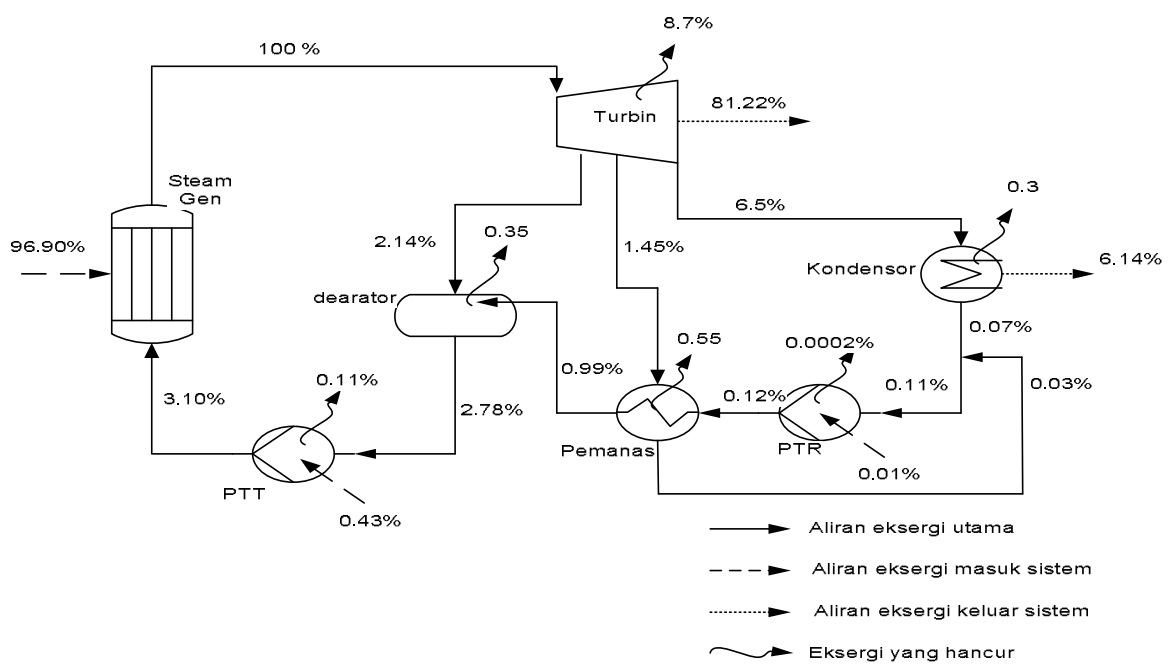

Gambar 4b. Distribusi Eksergi (\%) pada Untai Sekunder

Tabel 3. Irversibilitas Komponen Dalam Sistem

\begin{tabular}{lccc}
\hline \multicolumn{1}{c}{ Komponen } & $\begin{array}{c}\text { Energi } \\
(\mathbf{k J} / \mathbf{s})\end{array}$ & $\begin{array}{c}\text { Ireversibilitas } \\
\mathbf{( k J )}\end{array}$ & \% Ireversibilitas \\
\hline Reaktor & $9.999,28$ & $4.216,64$ & 61,800 \\
Pembangkit uap & $10.240,09(-)$ & $1.909,70$ & 27,989 \\
Sirkulator helium & 240,82 & 13,88 & 0,203 \\
Turbin & $3.437,97(-)$ & 366,75 & 5,375 \\
Kondensor & $6.820,86(-)$ & 272,61 & 3,995 \\
Mixer & & 0,24 & 0,004 \\
PTR & 0,68 & 0,10 & 0,002 \\
Pemanas Tertutup & & 23,98 & 0,351 \\
Dearator & & 14,73 & 0,216 \\
PTT & 18,07 & 4,44 & 0,065 \\
& & $6,823.07$ & 100.0 \\
\hline
\end{tabular}

Tanda (-) minus berarti sistem melakukan kerja terhadap lingkungan 


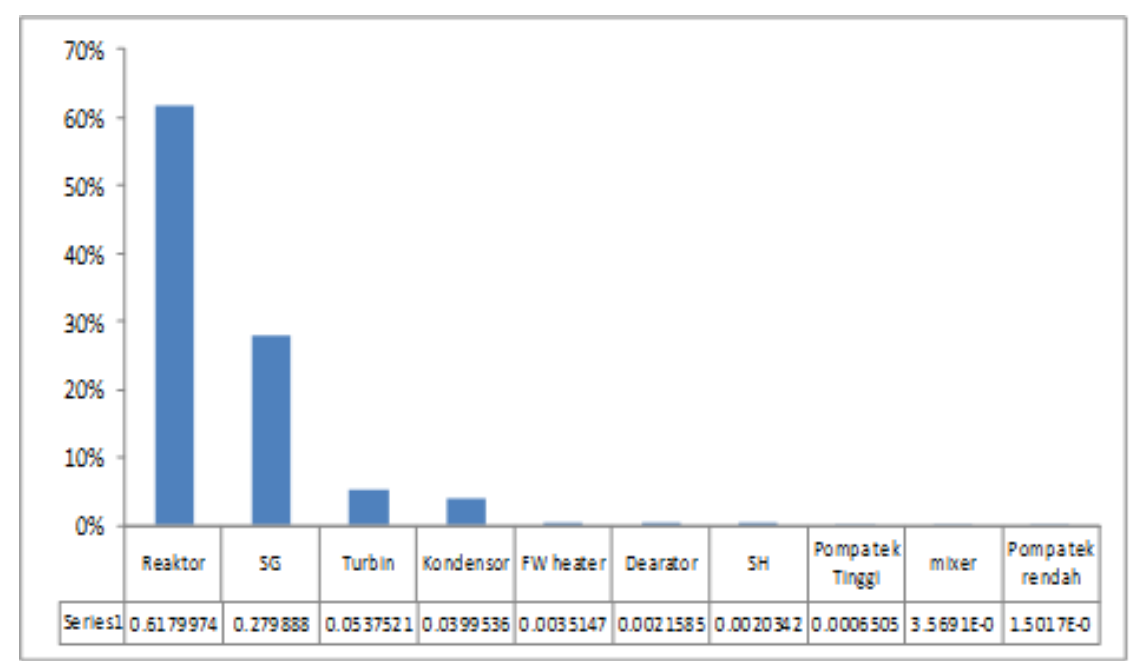

Gambar 5. Grafik Persentase Ireversibilitas Komponen

\section{KESIMPULAN}

Hasil studi analisis dan evaluasi terhadap ireversibilitas sistem reaktor HTGR menggunakan siklus turbin uap menunjukkan bahwa reaktor merupakan komponen yang paling tidak efisien dari seluruh komponen yang ada dalam sistem. Reaktor menyumbang $61,8 \%$ ketidaksefiseinan dalam sistem HTGR siklus turbin uap. Hal ini disebabkan ireversibilitas yang terjadi dalam transfer energi hasil reaksi pembelahan ke pendingin helium. Ireversibilitas yang terjadi ini merupakan total ireversibilitas dari sub komponen reaktor yaitu ireversibilitas reaksi pembelahan, ireversibilitas bahan bakar nuklir dan irevesibilitas pendingin helium. Pembangkit uap, turbin, kondensor, adalah komponen penyumbang terbesar berikutnya dalam ireversibilitas sistem HTR-10 siklus turbin uap masing-masing 27,9\%; 5,4\% dan 3,9\%. Hasil ini menunjukkan bahwa HTGR siklus turbin uap mempunyai potensi yang besar untuk perbaikan efisiensi sistem. Hasil ini juga menunjukkan lokasi dimana perbaikan efisiensi dapat dilakukan sehingga mampu memberikan efek yang signifikan terhadap perbaikan efisiensi sistem.

\section{DAFTAR PUSTAKA}

[1]. BREY. H.L., "Development History of The Gas Turbine Modular High Temperature Reactor".Vail, Colorado, United States of America, 2000

[2]. BEJAN A., TSATSARONIS G., and MORAN A., "Thermal Design and Optimization", Wiley,New York, 1996

[3]. ROSEN MQ., SCOTT DS., “Energy and Exergy Analysis of Nuclear steam Power plant", Proceeding of the Canadian Nuclear Society, Toronto 1986

[4]. DUNBAR WR., MOODY SD., LIOR N., “Exergy Analysis of an Operating Boiling Water Reactor Nuclear Station", Energy Conversion and Management 1995

[5]. DURMAYAS A., YAVUZ H., "Exergy Analysis of Pressured Water Reactor Nuclear Power Plant", Applied Energy, Elsevier. 2000.

[6]. LIOR N., "Energy, Exergy and Thermoeconomic Analysis of Effect of Fossile Fuel Superheating in Nuclear Power Plant. Applied Energy, Elsevier 1996

[7]. WISNUBROTO, D.S., "Pengembangan Reaktor Daya Non Komersial, Strategi untuk Pemenuhan Bauran Energi Nasional”. Hateknas, Seminar Bidang Energi. 2014.

[8]. SUN Y., ZHANG Y., XU Y., "Study on Coupling a Gas Turbine Cycle to The HTR-10 Test Reactor", Beijing, China. 
Jurnal Pengembangan Energi Nuklir Volume 17, Nomor 1, Juni 2015

[9]. KOSTAS, T.J., "The Exergy Methode for Thermal Plant Analysis". Great Britain; Anchor Brendon Ltd. 1985

[10]. TODREAS NE., KAZIMI MS., "Nuclear System I: Thermal Hydraulic Fundamental”, Hemisphere Publishing Corporation. 1990 